\title{
SOBRE A TENDÊNCIA EVOLUTIVA DA MORFOLOGIA FOLIAR DAS GLOSSOPTERIDÓFITAS, MEDIANTE APLICAÇÃO DE ANÁLISE FATORIAL
}

M.E.Longhim ${ }^{1}$

M.E.C.B.Oliveira-Babinski²

As glossopteridófitas, grupo vegetal predominante na flora neopaleozóica gondvânica, são representadas por sete morfogêneros foliares principais, a saber: Euryphyllum Feistmantel, Rubidgea Tate, Palaeovittaria Feistmantel, Rhabdotaenia Pant, Gangamopteris MCoy, Glossopteris Brongniart e Belemnopteris Feistmantel.

Como as estruturas férteis de glossopteridófitas são, mais comumente, encontradas na forma de impressões e destacadas de suas folhas, suas morfologias e afinidades botânicas não foram ainda completamente compreendidas. Assim, muitas das idéias e interpretações sobre esse grupo vegetal são baseadas apenas sobre sua morfologia foliar.

Hipóteses sobre a seqüência evolutiva da morfologia foliar de glossopteridófitas têm sido desenvolvidas pela co-autora (OLIVEIRA, 1978; Bol.IG-USP, 9:91-95) e por SRIVASTAVA (1991; Geobios, 24(4):383-386), com base nos processos elementares da Teoria Telômica, em modelos propostos por autores europeus e chineses para outros grupos vegetais e também, com base na observação da distribuição estratigráfica desses morfogêneros foliares nas seqüências sedimentares gondvânicas.

Assim, foi sugerido que formas foliares oblongas, de nervação retinervada e apenas dicotomizada dariam origem a formas lanceoladas ou oblongo-lanceoladas, pelo encurvamento progressivo das nervuras em direção à margem, enquanto que aquelas da porção central iriam coalescendo-se paulatinamente, da base ao ápice, até originar uma nervura mediana.

\footnotetext{
1Estagiária, Departamento de Paleontologia e Estratigrafia, Instituto de Geociências, USP.

2Departamento de Paleontologia e Estratigrafia, Instituto de Geociências, USP.
} 
Além disso, em certas linhas evolutivas, a nervação secundária adquiriria caráter anastomosado. Imaginou-se, então, que a mensuração e tratamento estatístico de caracteres biométricos tais como ângulos de divergência e de curvatura e densidade da nervação secundária, quantidade de dicotomias e de anastomoses, etc..., em fitofósseis provenientes de determinados niveis estratigráficos, possibilitaria comprovar a veracidade da hipótese.

Essa hipótese vem sendo testada estatisticamente, desde 1987, sob várias metodologias, tratando dados biométricos extraídos de espécimes ou publicações referentes às Tafofloras de Cerquilho, SP (Tafoflora "A-B"), Criciúma-Bainha, SC (Taf. "C") e São Marcos, SC (Taf. "C"), Fluviópolis, PR (Taf. "D") e Rio do Rasto, PR (Taf. "E").

Estudando o inter-relacionamento entre as variáveis utilizadas (Modo $R$ da Análise Fatorial) apenas para os dados extraídos de espécimes das Tafofloras "A-B" e "C", a metodologia mostrou-se satisfatória na avaliação do comportamento evolutivo das formas foliares:

a) quantificando o grau de correlação entre as variáveis usadas;

b) verificando quais destas variáveis seriam as mais importantes para a caracterização morfográfica dos diferentes morfogêneros deste grupo vegetal; e ainda,

c) observando o grau de discriminação entre os espécimes considerados, a despeito de seu taxon genérico e/ou especffico e também, traçando as características morfográficas de cada tafoflora, através do estudo de diagramas de distribuição dos espécimes no espaço das variáveis.

Como resultado desse tratamento, concluiu-se que, das variáveis utilizadas, as que poderiam melhor representar fenômenos evolutivos, nesse grupo vegetal, seriam: ângulus de divergência $\theta$ de incidência das nervuras secundárias com a margem, largura $\theta$ número de veias constituintes do feixe mediano, quantidade de anastomoses (próximas à nervura mediana e marginais) e densidade de nervação (à meia distância entre "nervura mediana" e a margem).

As matrizes de similaridade obtidas foram muito úteis na verificação de correlações entre as variáveis utllizadas. Assim observou-se que:

a) variáveis largura e número de veias do feixe mediano apresentam correlação linear positiva alta, num mesmo nivel tafoflorístico.

b) a esperada correlação linear negativa entre a largura do feixe mediano e as medidas angulares de divergência e curvatura não foi confirmada, bem como a positiva entre largura e as medidas angulares de incidência sobre a margem.

c) a esperada direta proporcionalidade entre número de dicotomias e a largura foliar foi verificada; entretanto, a correlação linear negativa entre o número de anastomoses e essa 
largura não foi confirmada. Isso pode ser decorrente da falta de dados provenientes de niveis estratigráficos superiores onde, provavelmente, essas correlações seriam mais nítidas.

Com base nos resultados obtidos, torna-se notória a necessidade de aplicar esse método a dados de níveis estratigráficos do Permiano Superior, bem como, tratar todos esses dados por outros métodos estatísticos já aventados. 